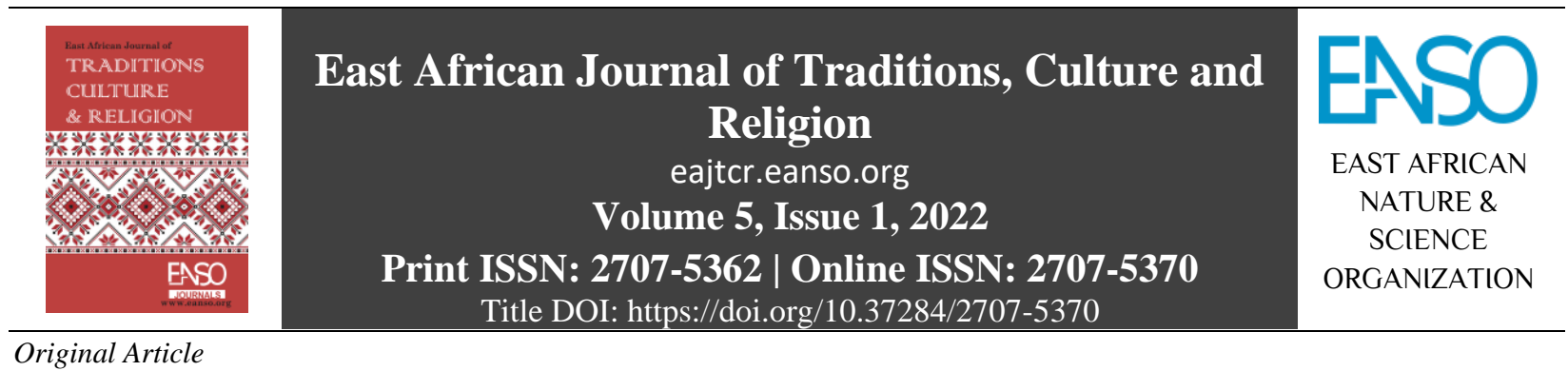

\title{
The Forgotten Heroes of Independence: A Case of Dr. Taaita Toweett.
}

\author{
Rodgers Kiplangat ${ }^{*}$, Dr. Isaac Kipsang Tarus, $\mathrm{PhD}^{1} \&$ Dr. Dorothy Nyakwaka, PhD ${ }^{1}$ \\ ${ }^{1}$ Egerton University, P. O. Box 536, Egerton, Kenya. \\ *Author for Correspondence Email: rodgerkigen@gmail.com
}

Article DOI: https://doi.org/10.37284/eajtcr.5.1.554

Date Published: ABSTRACT

17 February 2022 This paper studies on the struggle and undertakings of Dr Taaita Toweett towards the achievement of independence of Kenya from 1958 to 1964. The

Keywords: paper starts by ventilating on the background of Toweett from childhood to the time he plunged to politics in 1958. The paper focuses on two objectives,

Charismatic,

Taaita Toweett,

Independence,

Lennox-Boyd,

Historiography. contribution and legacies of Toweett towards achievement of independence. The paper uses the great man theory postulated by great historian Thomas Carlyle. The theory describes the influence of the leaders like Napoleon and Shakespeare in ancient societies thus applicable in the analysis of Toweett activities in the straddle for independence in Kenya. Qualitative methodology and historical technique were used in data collection while historian research design and purposive sampling were the main techniques used to identify the oral informants. Archival information was also a source of written data collected. The main themes which guided this research paper are the emergence of Toweett into active politics in 1957, the first Lancaster House conference of 1960, the formation of National political parties and the second Lancaster House conference of 1962.

\section{APA CITATION}

Kiplangat, R., Tarus, I. K. \& Nyakwaka, D. (2022). The Forgotten Heroes of Independence: A Case of Dr. Taaita Toweett. East African Journal of Traditions, Culture and Religion, 5(1), 1-14. https://doi.org/10.37284/eajtcr.5.1.554

\section{CHICAGO CITATION}

Kiplangat, Rodgers., Isaac Kipsang Tarus \& Dorothy Nyakwaka. 2022. "The Forgotten Heroes of Independence: A Case of Dr. Taaita Toweett”. East African Journal of Traditions, Culture and Religion 5 (1), 1-14. https://doi.org/10.37284/eajtcr.5.1.554.

\section{HARVARD CITATION}

Kiplangat, R., Tarus, I. K. \& Nyakwaka, D. (2022) “The Forgotten Heroes of Independence: A Case of Dr. Taaita Toweett”, East African Journal of Traditions, Culture and Religion, 5(1), pp. 1-14. doi: 10.37284/eajtcr.5.1.554.

\section{IEEE CITATION}

R. Kiplangat, I. K. Tarus \& D. Nyakwaka. "The Forgotten Heroes of Independence: A Case of Dr. Taaita Toweett", EAJTCR, vol. 5, no. 1, pp. 1-14, Feb. 2022.

1 | This work is licensed under a Creative Commons Attribution 4.0 International License. 


\section{MLA CITATION}

Kiplangat, Rodgers., Isaac Kipsang Tarus \& Dorothy Nyakwaka. "The Forgotten Heroes of Independence: A Case of Dr. Taaita Toweett”. East African Journal of Traditions, Culture and Religion, Vol. 5, no. 1, Feb. 2022, pp. 1-14, doi:10.37284/eajtcr.5.1.554.

\section{INTRODUCTION}

This article is about the constitution struggles of Taaita Toweett towards the attainment of self-rule in Kenya. Taaita Towett's history has not been documented in history books as one of the independence fighters in Kenya and yet he fought with a lot of zeal. The article unearthed the gist of his history and analysed his efforts and contributions towards the attainment of the independence. The article analysed Toweett's constitutional struggle from 1958 to 1964 . The article also examined Towett's early life to help lay a proper foundation on his political journey. It established that Toweett was born in 1925 to Christopher Chelogoi Arap Abosiek and Tabsaba Temugo in Chepwagan village, Litein area, Bureti constituency, Kericho County. Toweett entered active politics in 1958 when he was elected to Legco and later appointed assistant minister for agriculture in the colonial government in the same year. This marked the beginning of his constitutional struggle championed by Toweett.

The article employed semi-structured interviews in order to gather the required data for the study. Key informants included local administrators, county government officials, community members and the area leaders. Seventeen informants were sampled and included into the study together with the archival sources. Face to face interviews were conducted with the participant, observing the protocols put in place by the ministry of health to curb the spread of the corona virus.

\section{Figure 1: Portrait of Dr. Taaita Arap Toweett}

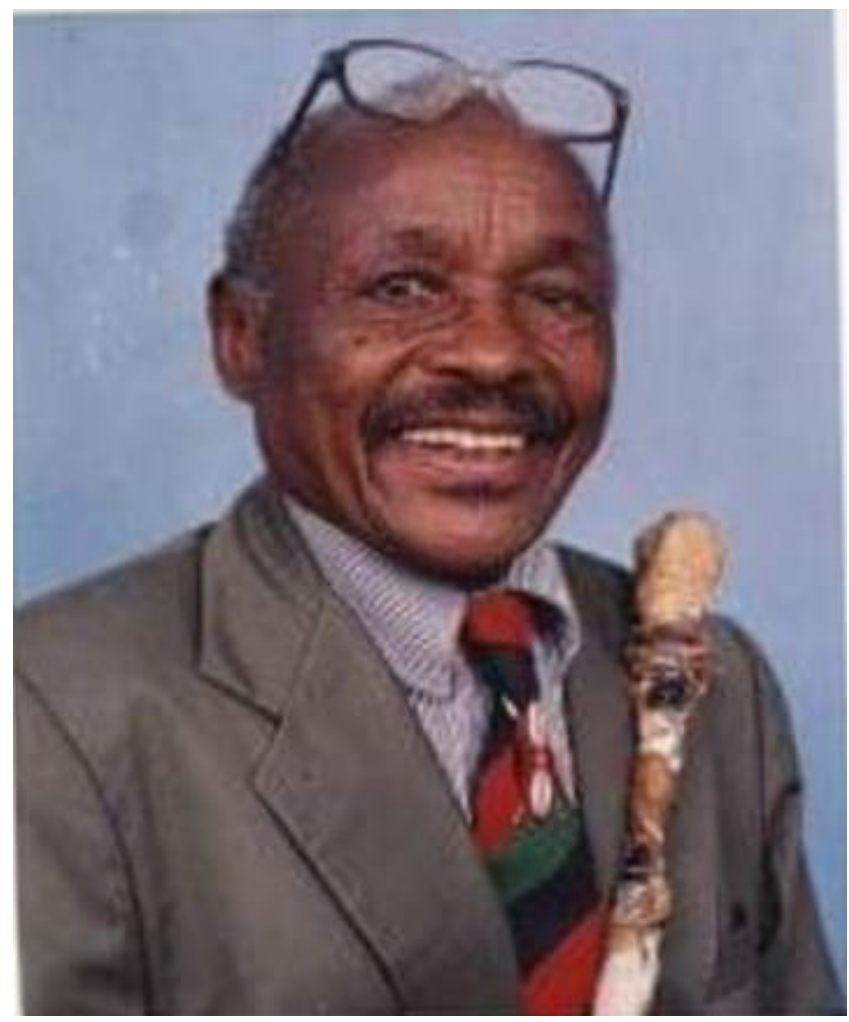

Source: Kenya National Archives Kericho

2 | This work is licensed under a Creative Commons Attribution 4.0 International License. 


\section{BACKGROUND OF THE STUDY}

Dr Taaita Toweett was born in 1925 to Christopher Chelogoi Arap Abosiek and Tabsaba Temugo in Chepwagan village, Litein area, Bureti constituency, Kericho County. ${ }^{1}$ Being the first born son, his grandfather named him Taaita, a name given to the firstborn's son and name Toweett was given to the lastborn son according to the Kalenjin Community. ${ }^{2}$ Toweett studied in mission schools for both his primary and secondary levels. ${ }^{3}$ Despite going to mission schools and attending church, Taaita Toweett was never baptized thus his name remained as given by the grandfather. ${ }^{4}$

The missionaries' education moulded and transformed Toweett to be a more responsible person even though he had been responsibly taking care of his siblings as from the age of ten when his mother passed on. ${ }^{5}$ In both primary and secondary school, Toweett served as a student leader, this equipped him with the leadership qualities and pushed him to join the political world and become a great leader. ${ }^{6}$ After the secondary level, he joined Makerere University where he pursued a Diploma in Sociology, English literature and history. Later after his diploma study, Toweett was appointed by the Europeans in Kericho District as junior Community Development Officer (CDO) to help in administrative duties. ${ }^{7}$ Due to his exemplary work, he was later elevated and appointed as the first senior African Community Development Officer.

In 1953, Toweett got a scholarship award from the Kipsigis county council to further his studied in South Devon Technical College Torquery where he undertook a Bachelor's Degree in public and social

\footnotetext{
${ }^{1}$ Peter Kitur, OI, 20 July .2021.

${ }^{2}$ Grace Mursoi, OI, 21 July 2021.

${ }^{3} \mathrm{KNA} / \mathrm{EP} / \mathrm{KCO} / 4 / 2 / 1$, A publication of Africa Books Service, 1956, p 83.

${ }^{4}$ Christopher Cheruiyot, I, 20 July. 2021.

${ }^{5}$ Ibid.

${ }^{6}$ Unsung Heroes of Lancaster: Call a Spade a Spade Historical Memoir 2011, longhorn publishers, p 11.

7 Weekly Review, A new political Equation in Kericho ,1988. $\mathrm{P}, 7$.

${ }^{8}$ https://en.wikipedia.org/w/index.php?title=Taaitta_Toweett \&oldid=788808568 accessed on 21 June 2021.

${ }^{9}$ Joseph Too, OI, 18 July 2021.
}

administration. ${ }^{8}$ After his study, Toweett came back and was reappointed by Europeans to CDO in Nandi district in $1956 .{ }^{9}$ While serving as CDO Toweett emerged to be a nationalist, charismatic person who always advocated for the Africans who were enslaved by Europeans ${ }^{10}$.

In 1957 general elections, Toweett plugged himself to elective position; he contested for Southern Electorate position where he lost to Lawrence Gerald Ogunda. ${ }^{11}$ In 1958, Lennox-Boyd constitution was introduced and created additional new constituencies and gave another chance for Toweett to contest for Kericho-Narok district representative and he won. ${ }^{12}$ Thereafter, he was appointed as an Assistant Minister for Agriculture and co-opted member of the Cabinet. ${ }^{13}$

Toweett is associated with the unity of Africa leaders from 1958 he participated in formation of Africans elective leaders' organization (AEMO) in February 1957. ${ }^{14}$ After sharp division in AEMO, Toweett opted to form political parties in 1959, Kenya National Party (KNP) and Kenya Independent Movement (KIM). ${ }^{15}$ The formation of all these parties aimed at uniting Africans leaders towards the fight for achievement of independence.

In 1960, Taaita was one of the leaders who were appointed to represent Africans in the First Lancaster House Round Table where Constitutional matters were discussed. ${ }^{16} \mathrm{He}$ earned his appointment due to his eloquence and charismatic nature. After he came back to Kenya in 1961, he was appointed Minister for Lands, Survey and Town Planning. ${ }^{17}$ In 1962, he was reappointed to represent Africans in the second Lancaster round table talks, a conference which earned the country

\footnotetext{
${ }^{10}$ Ibid.

${ }^{11}$ Isaac Kokwet, OI, 22 July, 2021.

12 KNA/KC/HE/KCO/3/Annual Report Kericho District 1959, P 3.

${ }^{13}$ Ibid.

$14 \mathrm{KNA} / \mathrm{KC} / \mathrm{CU} / \mathrm{EP} / 2 / 5 / 3$, Legislative Council Debate, Formation of Africa Unions, 1958 p 436.

$15 \mathrm{KNA} / \mathrm{CR} / \mathrm{KC} / \mathrm{FA} / 69 / 7 / \mathrm{We}$ ekly Review, Division Among Africa Leaders, $1^{\text {th }}$ June 1959.

${ }^{16}$ Samweal Kitur, OI, $21^{\text {st }}$ July 2021.

17 KNA/DC/PC/NC/2/Legislative Council Debates, Official Reports, Volume xi 1961, p, 780.
} 
independence in $1963 .{ }^{18}$ During these two conferences Toweett emerged a fighter and nationalist who tabled the Africans demands in presence of colonialists. ${ }^{19}$

Taaita was a pioneer and supporter of two giant political parties KADU and KANU which were formed in 1963; these two parties were the vehicles to achievement of independence in $1964 .{ }^{20} \mathrm{He}$ was one of the leaders who fought for the release of Mzee Jomo Kenyatta who was in captive in Lordwar, Jomo was one of the pillars in Africans leaders. $^{21}$ Toweett contributed immensely in the achievement of independence of Kenya through uniting Africa leaders to work towards one goal and using constitutional means. $\mathrm{He}$ is the leader who worked in colonial and independent governments, a history worth being unearth and explored.

\section{Statement of the Problem}

Taaita Toweett participated in both the first and second Lancaster Round Table talks in 1960 and 1962, he served in colonial and independent governments as Cabinet Minister. His legacies and political activities towards attainment of independence of Kenya have not been analysed and unearth to the limelight in history of Kenya. Therefore, this work aims at analysing contributions of Toweett towards the attainment of independence of Kenya from 1958 to 1964. The objectives of the study were:

- To examine the emergence of Toweett to elective positions.

- To analyse the contributions and legacies of Toweett to achievements of independence of our country Kenya.

\section{THEORETICAL FRAMEWORK}

This paper employed the Giant Man Theory of history. The Giant Man Theory was developed by

\footnotetext{
${ }^{18}$ G. O, E, Gona, Political Biography of Ronald Gedion Ngala, 1991. p 65.

${ }^{19}$ Wilfred Njogu, OI, $20^{\text {th }}$ July 2021.

${ }^{20}$ Frankline Ngetich, $20^{\text {th }}$ July 2021.

${ }^{21}$ Johnson Rugut, OI, $19^{\text {th }}$ July 2021.
}

great historian Thomas Carlyle. ${ }^{22}$ Carlyle analysed his thoughts about great man in his book entitled Heroes and Hero Worship which was published in 1841. Thomas built his perception on the history; he perceived that history depended on the great persons in the world. ${ }^{23} \mathrm{He}$ described the influence of the leaders like Napoleon and Shakespeare as an example.

This theory postulates on two main assumptions that, leaders are born and there is no leader who is made, secondly it perceives that leader always intervene in times of need to his subjects. The theory is also associated with the histories of Herodotus and Thucydides.

The historiography of great leaders and kings in $12^{\text {th }}$ and $13^{\text {th }}$ centuries changed the societies and royal courts to betterment. This school of thought of Carlyle got immense support in 1776 during the American Revolution, this year the historians took the great people as teachers of the society because of the good legacies they set in transforming the societies. ${ }^{24} \mathrm{He}$ meant that the destiny of the society depends on the power of the great men. To him social gatherings were not significant since the great men in the society were the pillars.

This theory has greatly contributed to the development of history. Carlyle argues that it is the humanity that manipulates the racecourse of history. He never took history in totality and already took the course; he considered any other happenings on the path.

Additionally, the great man theory put importance on the traits of the person. Carlyle says that traits are the compelling factors to growth of human development and human history. ${ }^{25}$ Toweett in all his undertakings in various positions he was appointed in both colonial and independent government, he might not have been great man but he portrayed the nationalistic nature in the fight for independence of

22 T. Carlyle, On Heroes, Hero-Worship, and the Heroic in History, (James Fraser Publishers, 1841), p, 101.

${ }^{23}$ Ibid.

24 J. Stephen, The hero as Divinity. (California: Publishers, 1841), p.3.

25 T. Carlyle, On Heroes, Hero-Worship, and the Heroic in History, (James Fraser Publishers, 1841), p, 178.

4 | This work is licensed under a Creative Commons Attribution 4.0 International License. 
Kenya, which according to Carlyle he manipulates the destiny of our history as Kenyans.

This approach of Thomas is applicable to this paper given that it stands on three tenets which describe Toweett in course of his leadership, charismatic, intelligence and power he possessed as a great man. ${ }^{26}$ Toweett was a charismatic and persuasive leader during his time and very intelligent in any decision he made in the entire course of his leadership. Carlyle defended his approach by saying that change of history entirely depends on the charisma of a leader. He gave an example of great poet who influenced ancient societies through poems.

However, Herbert spencer pointed out that the great men which Carlyle argued his thoughts are products of the social environment thus all illustrations should be from the social environment since it all contributed to the course of history. ${ }^{27}$ Herbert added that the approach only explains the impacts of the political aspect to the course of history and leaves out the cultural and social aspects. ${ }^{28}$ Despite the weaknesses identified by Spencer, the approach is relevant in unearthing the legacies of Toweett. This theory helps in analysing the undertakings of Taaita in the fight and achievement of Kenya independence in 1964.

\section{METHODOLOGY}

This paper basically uses qualitative method to collect data. This method covered analysis of the research problem. The list of relevant questions was prepared to ease the data collection in the field. The scrutiny of the data in documentary gives elaborate and useful knowledge on the leadership with specific reference of Dr Taaita Toweett.

\section{Research Design}

This paper utilizes the historical research design. This design is the conclusive analysis of the past events to produce a precise interpretation of the events. The design has four tenets: Identification of the research problem, collection evaluation of data, analysis of the information and finally interpretation

\footnotetext{
${ }^{26}$ Ibid, p, 182.

27 H. Spencer, Essay; Scientific, Political and Speculative (American Philosophical Society Publishers 1974), p 74.
}

and analysis of the results ${ }^{29}$. The design explores and unearths the legacies which Toweett left during the struggle for independence of Kenya.

\section{Sampling Procedure}

The main technique used to identify the informants was purposive sampling. The identity was as per the age of informant, the relationship with Toweett and the length of stay in Bureti constituency. Snowballing was also helpful as it fastened the research in identification of the reliable interviewees. Qualitative analysis of data collected from primary and secondary sources was done. Comprehensive summary of data was done finally through discerning, examining, contrasting and interpretation of the final results of the research.

\section{Data Collection}

Historical writings always depend on the historical documents and oral informant. These two sources were utilized to write this paper. Written sources were obtained from books, journal, newspapers, biography, and autobiography. Primary data were gathered in the national achieves and from the oral interviewees. Toweett wrote several books about the struggle for independence, these books form part of the documentaries used in this paper. Timetable for interview schedule was used to ease the research and good management of data. Camera was used during the research to capture photos and voice recorder to record the voices of the informant. Kiswahili, English and Kalenjin were the common languages used to collect data. Oral data was collected with the agreement of the informant; thereafter transcription of data was done. Secondary data was collected concurrently with the primary data. This research largely depended on the Egerton university library, Kenya National Achieves and Nakuru National library. All the data collected aimed at meeting the objectives of this work.

\section{Data Analysis}

Analysing the collected data was founded on the objectives and theoretical approach of this paper to allow decoding of the legacies and undertakings of

\footnotetext{
${ }^{28}$ Ibid, p. 101.

${ }^{29}$ M. Edward, The Research Project; Planning and designing your work, $2^{\text {nd }}$ Edition (Sage Publication ,2012), p. 16.
}

5 | This work is licensed under a Creative Commons Attribution 4.0 International License. 
Toweett in the struggle for independence. The analysing also helped in separating the relevant from irrelevant data collected by sieving the useful data, data needed to achieve the objectives of the paper.

Analysing and transcription of data was done after the research. The findings and evaluation of the data collected regarding the legacies of Toweett in fight for independence were related from the objectives achieved from the field. Thereafter, it was combined with the data collected from the secondary sources. After successful collaboration of data from primary and secondary sources, a comprehensive conclusion was drawn.

\section{FINDINGS AD DISCUSSIONS}

\section{The Emergence of Toweett to Elective Positions From 1957 to 1958}

Toweett political journey started in 1957 when he contested for position to LEGCo. ${ }^{30}$ A part from his interest to contest in general election of 1957, his leadership interest started since childhood and it was not by surprise that he plunged himself into discretionary post. ${ }^{31}$ Besides his personal interest of vying for the post, elders drawn from Kericho saw him fit because he was dedicated hardworking intelligent and charismatic young person..$^{32}$ Additionally, his intention got support from his home area given that he had worked for the Europeans in tea plantation and he understood the grievances of African workers who were enslaved to pluck tea with little payments. ${ }^{33}$

The introduction of the Lyttleton plan in 1956 created and increased the number of representatives in the LegCo. ${ }^{34}$ The plan made the Kenyan politics advanced as it gave Africans eight representatives and appointment of a cabinet minister and a Secretary to the LegCo. ${ }^{35}$ Additionally, the cabinet was tasked with collective responsibility. The plan

\footnotetext{
${ }^{30}$ Sammy Siele, OI,21 ${ }^{\text {st }}$ July 2021.

${ }^{31}$ Ibid.

32 Ibid.

${ }^{33}$ Ibid.

${ }^{34}$ KNA/PC/DC/KCO, Annual Report Kericho District, 1957, Vol 78.

${ }^{35}$ KNA/PC/NC/KCO, Kenya Legislative Council, 1959, p, 94.
}

also gave power to the ordinary people to elect members to the LegCo by direct vote and the winner was anyone with the majority votes. Despite of the Europeans using the same plan to undermine the African leadership, it gave a chance for Toweett to venture into politics and start leadership journey. The recommendations proposed by Lyttleton Plan was approved and implemented in 1957 election where Toweett contested for Southern Electorate Area and lost to Gerald Ogunda. ${ }^{36}$ Toweett was contesting against an experienced and long serving leaders in Kenyan politics and civil servants but he emerged the second, this motivated him to even contest in future political positions.

After ruthless and continuous vindication of the African elected leaders to the LegCo, the government of Kenya brought Lennox Boyd constitution in 1957. Some of the recommendations of this constitution favoured Africans and other marginalized group. It received mixed reactions from the elected leaders. ${ }^{37}$ The coastal region leaders said that African grievances had been settled while the Nairobi, Central and Rift valley region perceived that the constitution was another Lyttleton plan which was proposed to marginalize Africans. $^{38}$ Lennox Boyd recommended the increase in African representation in LegCo from eight to fourteen but retained the Ministerial way of governance and this made African leaders to refuse the proposal of Lennox.

Additionally, African leaders were against the idea of nomination positions imposed and stipulated in the Lennox. The recommendation added special seats for the Europeans to the LegCo and created council of state which was responsible for implementation of any acts of legislative council. African leaders saw this as a way of blocking the demands and any act of African elected leaders in LegCo. ${ }^{39}$ It was the main aim of Europeans to use the state council pave way for their objectives to be achieved with ease. The proposal of Lennox was

\footnotetext{
36 KNA CB/CP/NC/1/2/309. Nahasion Philip Manzon and Lennox-Boyd on Aspirants Contesting.

${ }^{37}$ Raphael Koech, OI, $23^{\text {rd }}$ July 2021.

${ }^{38}$ G. W. Gona, A political biography of Gideon Ngala; MA Thesis University of Nairobi; 1991. P 131.

${ }^{39}$ Kenduiwo Jonathan, I, $23^{\text {rd }}$ July 2021.
}

6 | This work is licensed under a Creative Commons Attribution 4.0 International License. 
forcefully passed and it created six additional constituencies in Kenya, the act passed with the absence of the African elected leaders in the House. ${ }^{40}$ The recommendations of the Lennox were immediately implemented and the date of elections was set. The European government was very vigilant in the type of African leaders who were going to be elected to position created by the Lennox, it wanted Africans who would cooperate and support the government agendas.

Lennox Boyd constitution gave a chance to Toweett in 1958 to contest for Narok-Kericho District representation in Legco. ${ }^{41}$ Elections were scheduled to February 1958 and most of those who were defeated in 1957 election got opportunity to make a trial. Toweett emerged a winner in Narok-Kericho district territory, some of the leaders elected along with him were Julius Ole Tipis representing central Rift, John Nyagah representing Embu, Joseph Khamisi representing Central, Kiano Kikonye representing Mombasa and Mumo Ngatia David representing Ukambani. ${ }^{42}$ After election of these members, the representation of Africans expanded and it strengthen the unity. This election also gave chance to high percentage of Kenyan tribes to be in Legco and every leader was looking for anyway his community could be favoured in the government and this brought about differences in African elected leaders in Legco. ${ }^{43}$

Figure 2: Photo of Dr. Taaita Toweett in 1958 when he was elected member representing Southern Electorate area, Kericho and Narok

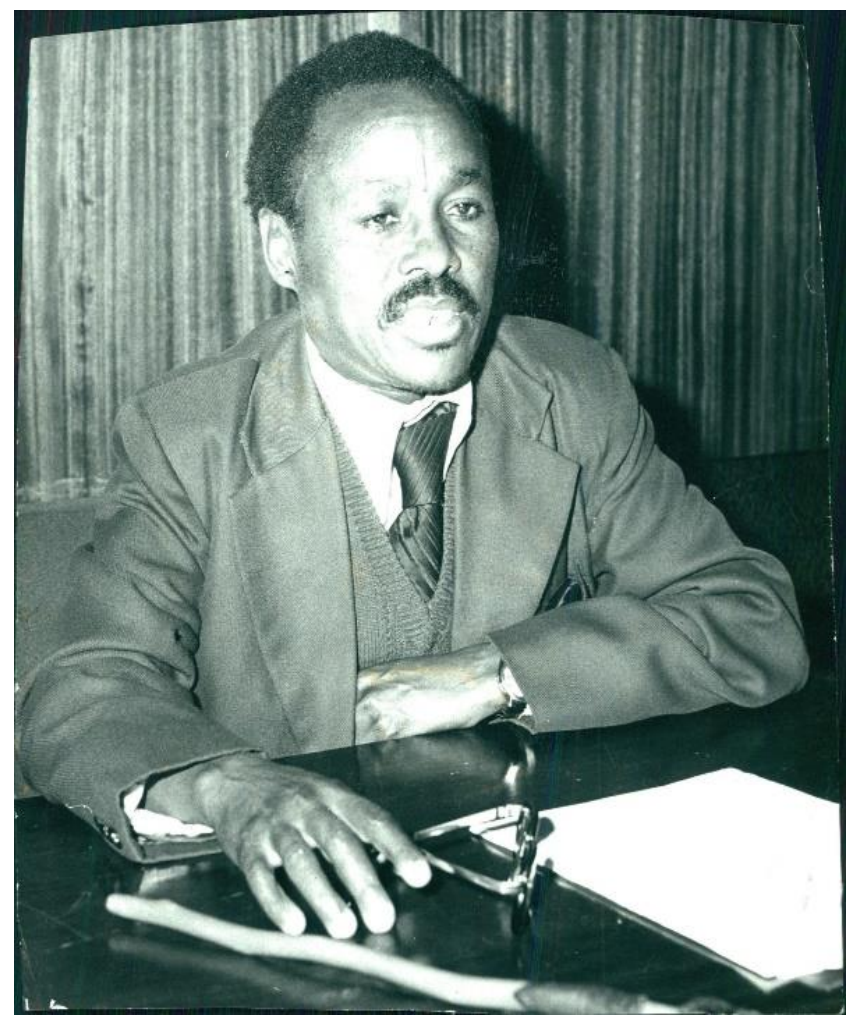

Source: Kenya National Archive Kericho

In 1958, the differences emerged among African leaders which led to formation of African elected members organization (AEMO), this aimed to bring the unity and bond stronger. Oginga Odinga was

\footnotetext{
42 KNA/KC/NA/DC/5/9/2, Kericho Times, Victory of Toweett Taita, 1958, P .4.

${ }^{43}$ Richard Tegutwo, OI, $23^{\text {rd }}$ July 2021,
}

7 | This work is licensed under a Creative Commons Attribution 4.0 International License. 
elected the chair person, Ronald Ngala vice chair, Tom Mboya general secretary and Toweett was elected coordinator and organizer of the union. ${ }^{44}$ Toweett was composed and quit a leader; this earned him the opportunity to coordinate all the activities of the organization. His duty was to convey meetings and bring cohesion among the members and make them stick on one objective of fighting for independence. Toweett brought back the unity of the African leaders thus making him honourable and be respected among the elected leaders.

In 1958 March, the council appointed Ngome Gideon, Emalamba Moses, Michael Wanjoru and Machariah Joseph to council of Ministers. ${ }^{45}$ African leaders were against the appointment of the four leaders because they perceived them as traitors. Few days after the appointment of the four, some of the AEMO leaders hold a press conference and the government took it as lack of respect and trust to the European leadership. Toweett was among those against the nomination done by the government. The AEMO leaders were charged and found guilty of lacking respect to the government proposals thus they were subjected to a penalty of Eighty thousand Kenyan shillings. ${ }^{46}$

In April 1958, Toweett organized a meeting with African leaders with an objective of telling the government about the urge and need to amend and introduce a new constitution in Kenya but their request to the government were not heard. They later requested for a meeting with the governor of Kenya, Evelyn Baring in June 1958 but this was also declined. ${ }^{47}$ After several attempts with no success, they then wrote a letter to the Governor of the Colony and were told to wait for the response. Governor's visit of 1958 Kenya gave hope to the AEMO leaders as they thought they could be given a chance to air their grievances but this was also rejected. Day one of the governor's address to the

\footnotetext{
$44 \mathrm{KNA} / \mathrm{ND} / \mathrm{DC} / \mathrm{KC} / 2 / 3 / 5$, Kericho Times, Appointment of Toweett, 1959. p.5.

$45 \mathrm{KNA} / \mathrm{DC} / \mathrm{FC} / \mathrm{KCO} / 8 / 5 / 2$, Legislative Council Debates, 1959 , p. 14.

46 T. Toweett, Epitaph on Colonialism and Shorter Poems, (Longhorn Publishers; 1989), p. 41.

${ }^{47}$ Hillary Chepkwony, OI, $21^{\text {st }}$ July 2021.

${ }^{48}$ Ibid,
}

LegCo clearly showed that the AEMO leaders would not get a chance to present their proposal; this made them protest by moving out of the LegCo in the middle of her address thus leading to adjournment of the address for four days. ${ }^{48}$

On October $10^{\text {th }} 1958$, governor urged the African leaders to have a meeting with him. He apologized for not discussing on African grievances but the African leaders perceived the meeting objective as a way of convincing them to attend the LegCo meeting. ${ }^{49}$ The African leaders chose to abstain from the LegCo meetings until their proposals were respected. ${ }^{50}$ Some of them had suggested that they resign from the LegCo but Toweett advised them that it was not the best option thus he encouraged them to boycott the LegCo meetings until the time Richard Turnbull the Colonial Secretary respond to their demands. The year ended with no positive response from the colonial secretary and governor. ${ }^{51}$

In 1959, European used divide and rule strategy to bring division among the elected leaders. They applied this because of the long persistent absence of the Africans and Asians in the LegCo and strong unity among Africans leaders through AEMO. ${ }^{52}$ Some of the African leaders attempted to bring division in the AEMO but the bond was stronger. AEMO leaders felt the impact of the protest and motivated themselves to continue with boycott. They wanted self-governance and uniform development in the country, but Europeans aimed at exhausting and harvesting raw materials of the country. Europeans realized the unity of Africans and started training the whites on how to conquer them. They introduced new rules on laborers with an objective to shape the unities they have and undermine the support African leaders have among the ordinary citizens.

The nationalism movement gained the momentum in 1959 and the whole continent Africa started demanding for independence. ${ }^{53}$ The continuous

\footnotetext{
49 T. Toweett, Epitaph on Colonialism and Shorter Poems, (Longhorn Publishers; 1989), p. 64.

${ }^{50}$ Frankline Bett, OI, $20^{\text {th }}$ July 2021.

${ }^{51}$ Ibid.

${ }^{52}$ KNA/DC/NA/2/4/3, Legislative Council Debates 1959. vol xii p. 123.

${ }^{53} \mathrm{KNA} / \mathrm{DC} / \mathrm{KC} / \mathrm{DC}$, weekly Review, The Start of Nationalism, 1959, p. 14.
}

8 | This work is licensed under a Creative Commons Attribution 4.0 International License. 
demand by the African leaders in Kenya on their grievances made the Europeans respect and pave way only for them to safeguard their interest in the territory. In February 1959, Toweett planned a meeting for Africans, Arabs, Asians and some of the whites who were supporting independence and they came up with Constituency Elected Members Organization (CEMO).$^{54}$ The CEMO composed of all the tribes in the country and they disbanded AEMO. CEMO was formed to strengthen the unity of Africans leaders and to avoid leadership wrangles which were building up in AEMO. CEMO moved on with one voice of agitating for common interest of bringing the constitutional change which would favour Africans. ${ }^{55}$ In 1959, CEMO sent representatives to a conference in Europe. The team was led by Kiano, Toweett, Muliro and Blandell and before they left to Europe, the Kenya Colonial secretary Richard Turnbull issued a statement that their grievances were being discussed. ${ }^{56}$ The statement issued by Turnbull gave African leaders hope on change of constitution. Despite the assurance by the colonial secretary, Toweett warned the team that they should not be happy but relax and be cautious on the intentions of Turnbull.

Toweett was one of the educated leaders, a good strategist and he was well conversant with constitutional matters. He advised his members to always engage and seek clarifications on any step they took. ${ }^{57}$ Toweett and his team attended the conference and sought for an opportunity to articulate the demands of the Africans. ${ }^{58}$ They wanted to change the constitution and do away with the Lennox Boyd constitution which was marginalizing the Africans. ${ }^{59}$ Their grievances were listened and the colonial government allowed the amendment of the Lennox constitution and after a long time, the Africans accepted to attend the Legco meetings.

After successful negotiations in the European conference, the Africans leaders led by Toweett as

\footnotetext{
54 Ibid.

55 Ibid.

56 T. Toweett, Unsung Heroes of Lancaster: Call a Spade a Spade Historical Memoir 2011, longhorn publishers, p 22.

${ }^{57}$ Weldon Tanui, OI, $23^{\text {rd }}$ July 2021.

${ }^{58}$ Ibid.

${ }^{59}$ Raphael Kitur OI, $20^{\mathrm{TH}}$ July 2021.
}

organizer started to lay down strategies on how to demand for speedy independence. Some African elected leaders wanted forceful means to get independence while Toweett and a group of nationalists wanted to use peaceful means to reach agreement on how Europeans would hand over power to Kenyans. ${ }^{60}$ Those with the idea of using force came up with a strategy of increasing the African representation sequentially in the running of government and finally overthrow the colonial government. The different approach brought about sharp differences between the elected leaders and the nationalist. Many Kenyans wished to use forceful means but Toweett stood and advised them on the importance of negotiations. The difference in the approach of gaining independence persisted and African leaders split and opted to form political parties. The two main parties that were formed are: Kenya National party (KNP) and Kenya Independent Movement (KIM). ${ }^{61}$ These parties were formed after the government allowed the formation of non-tribal parties in 1957. Toweett, Ronald Ngala and Gerald Ogunda never associated themselves with the formation of these political parties but they insisted on the united CEMO. Toweett kept on conveying CEMO meetings and illustrating the importance of African unity as they journeyed towards independence. ${ }^{62} \mathrm{He}$ knew that the only organization which African leaders would be heard was through CEMO.

\section{The First Lancaster House Conference in 1960}

Toweett was appointed to lead the delegation to the First Lancaster House Conference. ${ }^{63}$ This was constitutional meeting where the colonialists held a meeting with the African leaders, composed of CEMO members. Before they left for the conference, they advised themselves on the objectives they would work for united advocacy. They unanimously agreed to work together and channel their grievances as one voice in the conference. Muliro, Oginga Odinga and Tom

\footnotetext{
${ }^{60} \mathrm{KNA} / \mathrm{KC} / \mathrm{EP} / \mathrm{KC} / 5 / 6 / 7$, Kericho Times, Rise of Nationalism, 1959, p.67.

${ }^{61}$ Fredrick Ruttoh OI, 20 ${ }^{\text {th }}$ July 2021.

$62 \mathrm{KNA} / \mathrm{DC} / \mathrm{KC} / 2 / 4 / 5$, Legislative Council Debate, Official Reports ,1960/61, Volume IIX Section.

$63 \mathrm{KNA} / \mathrm{DC} / \mathrm{KC} / 3 / 6 / 8$, Legislative Council Debate, Official Reports, 1961, p. 12.
}

9 | This work is licensed under a Creative Commons Attribution 4.0 International License. 
Mboya were not appointed for the conference because of the disunity they brought in AEMO and CEMO. ${ }^{64}$ Toweett was appointed because of the good organization he portrayed in the AEMO and CEMO. Taaita was humble, educated and eloquent in expressing his issues and also very conversant with the constitution. He was the moderator and good organizer of AEMO conferences. ${ }^{65}$ Additionally, his objectiveness in the Africans organization earned him a good reputation among his fellow leaders. Lancaster was a platform which gave the African leaders a chance to articulate for their demands.

In March 1960, Patrick Renison was appointed to replace Evelyn Baring as governor of Kenya and Ian Macleod as the secretary of the colony of Kenya. Patrick and Ian became the leaders of the Lancaster conference. ${ }^{66}$ Brigg and Blandell were appointed to lead other races in the country. During the conference, the issue on the elections was also discussed. The Africans wanted a change in the system of voting whereby one man one vote policy would be appreciated and communal system be removed. After long deliberations, the Africans were allowed majority representation in the LegCo and this was gain for the Africans since this meant that all the decisions made in the LegCo, Africans would win and implement it. ${ }^{67}$ Ian Macleod proposed special seat for minority community which was to be appointed and recommended by African leaders in parliament. On that seating Toweett advised Africans leaders that they must take all the influential positions in the government to allow them restructure the running of the government. ${ }^{68}$ After the conference, the colony secretary accepted the demands of the Africans. It was a great achievement of African leaders as they returned to the country victorious.

Figure 3: Photo of Dr. Taaita Toweett and Lancaster delegates in 1960

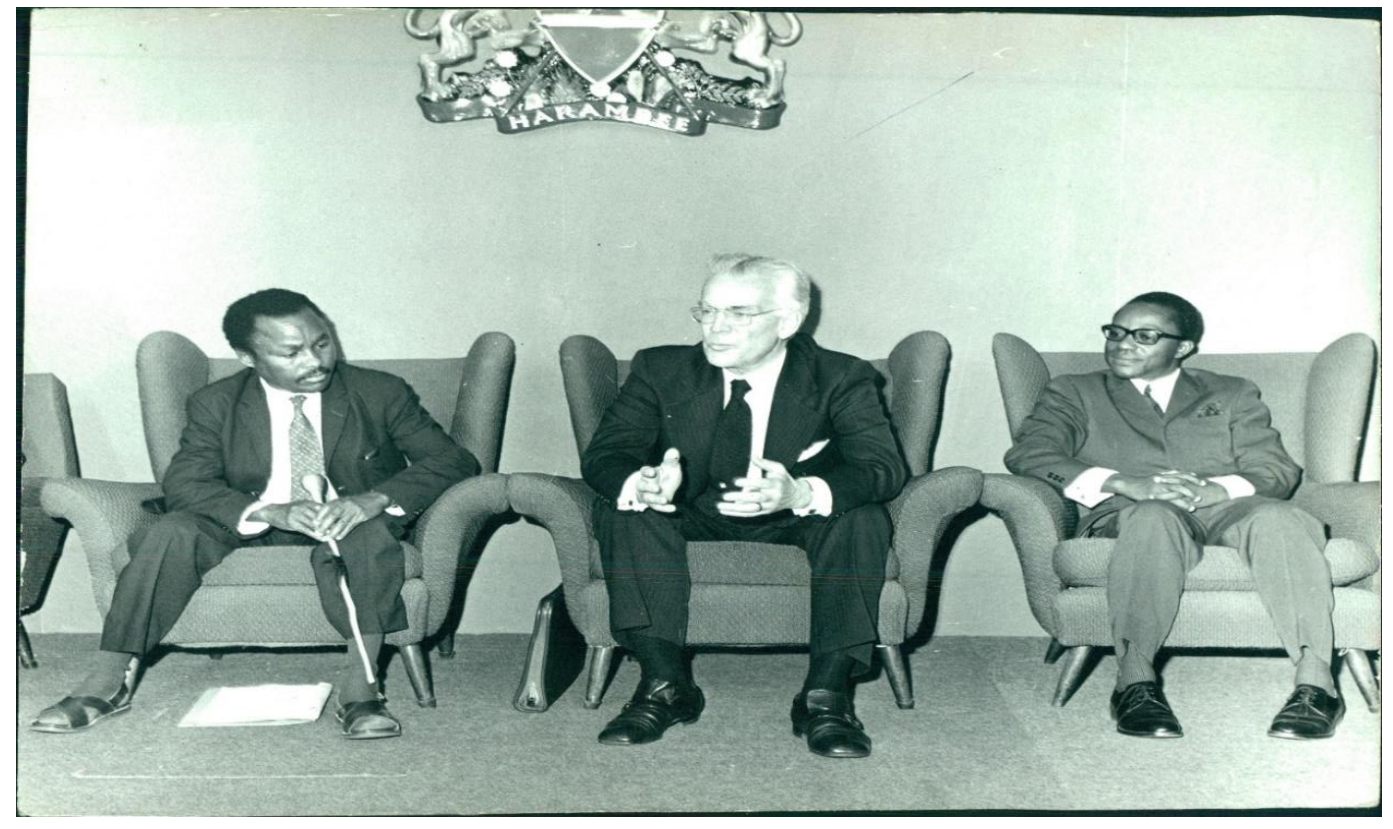

Source: Kenya National Archive Kericho

In 1961, interim secretary of the colony Elisha Jones appointed the African Ministers; this step was doubted by African leaders as it was not part of the proposals of the agreements of the Lancaster

\footnotetext{
64 T. Toweett, Unsung Heroes of Lancaster: Call a Spade a Spade Historical Memoir, (longhorn publishers), p .42.

${ }^{65}$ Jonathan Meiwo, OI, $21^{\text {st }}$ July 2021.
}

${ }^{66} \mathrm{KNA} / \mathrm{DC} / \mathrm{KC} / \mathrm{NC} / 5 / 8 / 1$, Legislative Council Dabates, 1961, Vol LXX

${ }^{67}$ Raphael Kitur, OI,21 ${ }^{\text {st }}$ July 2021.

${ }^{68}$ Ibid.

10 | This work is licensed under a Creative Commons Attribution 4.0 International License. 
conference. ${ }^{69}$ It was proposed that the council of ministers be appointed after the 1961 elections.

Toweett was ready to take the offer by Macleod, this triggered differences among African leaders and it resulted to rebirth of KNP and KIM parties whereby KNP accepted the appointment. ${ }^{70}$ Ronald Ngala was appointed minister for Social Welfare, Kiano minister for Commerce and Industrialization and Toweett was appointed as an Assistant Minister for Agriculture. ${ }^{71}$ Toweett as an Assistant was chosen to participate in council of ministers since he was deputizing a European who knew little about the Kenyan territory, Toweett got a good platform to articulate for Dr. Taaita Africans in the Cabinet. ${ }^{72}$ In the same year, 1961, Jomo Kenyatta who was the leader of Kenya African Union (KAU) was arrested and detained in Turkana. African leadership was sub staged with the Kenyatta imprisonment; he was key and fearless liberator of Kenya as he was seen as the kingpin of the Kenyan communities. All the appointed ministers promised to fight for the release of Kenyatta.

The appointment of Toweett to the Council of Ministers was not taken well by African leaders. ${ }^{73}$ They saw the acceptance of the appointment as betrayal since they wanted Kenyatta to be released before he could accept the appointment. Despite of this, Toweett accepted to take the position after a long deliberation with nationalists who subscribed to same ideology as they wait for the implementation of the Lancaster proposal. ${ }^{74}$ These positions acted as training grounds for the Africans leaders to know how to run the government on their own. This was also a milestone for the Africans to struggle towards achievement of independence. It was a direct channel for Africans leaders to channel their demand in the cabinet.

\footnotetext{
${ }^{69} \mathrm{KNA} / \mathrm{TC} / \mathrm{AN} / \mathrm{KC} / 3 / 9 / 1$, Weekly Review Appointment of Ministers, 1961, p. 14

${ }^{70}$ Raphael Kitur, OI,21 ${ }^{\text {st }}$ July 2021.

${ }^{71}$ G. W. Gona, A political biography of Gideon Ngala; (MA Thesis University of Nairobi; 1991). P 79.

${ }^{72}$ Raphael Kitur, OI, $21^{\text {st }}$ July 2021

${ }^{73}$ Ibid.

${ }^{74}$ Frankline Chepkoit, OI, $20^{\text {th }}$ July 2021.
}

\section{Formation of National Political Parties}

In 1960, there was need to form national political parties to ease the fight for independence. It took lengthy deliberations to come up with Kenya Uhuru party (KU) which was formed by the nationalists and the leaders who were not in the LegCo. ${ }^{75}$ The part gained support in all parts of the country. After Kenyans embraced the idea of forming national political parties, they held a conference in Kiambu in 1961 and formed KANU. Toweett was appointed as part of the transitional body for them to come up with comprehensive aims of the newly formed party. ${ }^{76}$ Gichuru James was appointed the chairperson and secretary general was given to Mungai Njoroge. Kenyetta was proposed by the party members to be the chairman while he was still in custody at Lodwar. ${ }^{77}$ Toweett was against the appointment of Kenyatta in his absence because this could make the registration of the party tedious. This is where the differences emanated from the newly formed party.

In 1961, there was reshuffle of the KANU leadership. Gichuru James remained the chairperson, Oginga Odinga was appointed the vice chair and Tom Mboya appointed the secretary general. ${ }^{78} \mathrm{KANU}$ members wanted the Legco leaders to resign in the Legco for them to contest using the KANU ticket. African elected leaders declined the request. KANU members additionally asked other small parties to disband their parties and join KANU, an idea which was not received well by other political parties as they claimed to have different aims and objectives. Other issues which brought division in the party were leadership wrangles. ${ }^{79}$ Some members felt that Odinga, Mboya and Njoroge wanted to take control of the party. Small communities felt discriminated as they saw that party leadership was taken by bigger tribes which were Luos and Kikuyus. These small communities feared the two tribes thus they decided

$75 \mathrm{KNA} / \mathrm{KC} / \mathrm{PC} / \mathrm{RC} / 6 / 02.5$, Weekly Review, Demands of Nationalists, 1961.

${ }^{76}$ Edwin Kirui, OI,21 ${ }^{\text {st }}$ July 2021.

${ }^{77}$ Ibid.

$78 \mathrm{KNA} / \mathrm{KC} / \mathrm{HC} / \mathrm{KC} / 4 / 7 / 9$, Weekly Review, Reshuffle in KANU, Leadership, 1961, p. 5.

${ }^{79}$ Andrew Tanui, OI, $22^{\text {nd }}$ July 2021.

11 This work is licensed under a Creative Commons Attribution 4.0 International License. 
to form their own political parties. ${ }^{80}$ In Rift Valley, the Kalenjins formed Kalenjin Alliance Democratic Unity party led by Daniel Arap Moi and Taaita Toweett in the year $1961{ }^{81}$ The main objectives of this party were to protest for retrieval of their land which had been grabbed by the whites and the kikuyus in the parts of Laikipia and Naivasha. Maasai community formed Maasai Movement United Party (MMUP) with the aim of demanding for their land too. ${ }^{82}$ The two parties later joined and came up with Kenya Alliance Democratic Union (KADU). Western Kenya communities led by Masinde Muliro formed Kenya Association Party (KAP). The Coastal region led by Ronald Ngala formed Mombasa African Peoples Party (MAPA). Ronald Ngala dominated the coastal region as he was a recognized leader in the region. All these communities' parties were formed due to the fear of the small communities that immediately Kenya gain independence, the bigger tribe would take all the positions in government.

In 1961 general elections, KANU and KADU were the main political parties to contest with. Toweett was a strong supporter of KADU. ${ }^{83}$ Both parties campaigned for the release of Kenyatta who was still in detention since he was a leader accepted the whole country. As one of the leaders of KADU, Toweett came out boldly and said that the party was in a forefront of fighting for the release of Kenyatta. He assured Kenyans that the Council of Ministers was supporting African grievances to be heard by the colonial government. ${ }^{84} \mathrm{He}$ promised to resign if the government did not listen to their demands. ${ }^{85}$ Toweett once said that he did not have a problem with the Europeans but he was against their political control in the country. He added that the Europeans would boost the economy of our country even after independence. Toweett as supporter of KADU liked the idea of multi-party government.

\footnotetext{
${ }^{80}$ Ibid.

${ }^{81}$ KNA/DC. KC/RC/3/7/8, Kericho Times, Political Formation, 1961. p 12.

82 Ibid.

${ }^{83}$ T. Toweett, 'Epitaph on Colonialism and Shorter Poems, (Longhorn Publishers; 1989), p. 36

${ }^{84} \mathrm{KNA} / \mathrm{KC} / \mathrm{DC} / \mathrm{NM} / 8 / 9 /$ Weekly Review, Kericho District Election, 1961, p,3.

${ }^{85}$ Alexander Kigen, OI,21 ${ }^{\text {st }}$ July 2021.
}

In the general elections of 1961, Toweett won the Southern Electorate seat which he was battling with Korir and Barmalel Arap Tarmason. ${ }^{86} \mathrm{He}$ was declared a winner with total votes of 59,490 thus represented the Kipsigis community in the LegCo. After the elections, the common goal of African leaders was to demand for the release of Kenyatta who was seen as symbol of unity for the Kenyans. All the elected leaders made an affirmation that Kenyatta must be released for them to form a government. KANU members were the majority in the LegCo and they were the ones to form the government as per the law. ${ }^{87}$ They rejected the slots given by the Europeans in the government. In February 1961 KADU members led by Toweett visited Kenyatta in Turkana Lodwar where they asked him on the way forward concerning the formation of the government. ${ }^{88}$ Even though Kenyatta was not up to leadership after his release, Toweett supported him because he believed he had good leadership skills as he portrayed in KAU party. ${ }^{89}$ KANU and KADU had organized a meeting with the Secretary of the Colony requesting for the release Kenyatta but it never bared any fruit. After unsuccessful meeting, KADU accepted to form the government as they saw it difficult to fight for Kenyatta's release and achievement of independence while outside the government. ${ }^{90}$ KANU members were against the formation of government. Toweett was convinced by the secretary of the colony. He was appointed Minister for Local Authorities and Lands, Ronald Ngala as Minister for Education and leader of business in the government while Masinde Muliro as minister of labour and housing. In September 1961, KANU members formed an opposition to the government which was led by Gichuru, Mboya and Oginga Odinga. ${ }^{91}$ KADU consistently agitated for the release of Kenyatta and in October 1961 the governor of Kenya Colony admitted that the request by KADU to free Kenyatta had been listened and

\footnotetext{
86 KNA /KC/DC/ER/3/5/9, Weekly Review, Victory of Toweett, 1961, p. 15.

${ }^{87}$ Ibid.

${ }^{88}$ T. Toweett, 'Epitaph on Colonialism and Shorter Poems, (Longhorn Publishers; 1989), p.67.

${ }^{89}$ Ibid, pp.

${ }^{90}$ Ibid, p. 82.

${ }^{91}$ G. W. Gona, A political biography of Gideon Ngala; (MA Thesis University of Nairobi; 1991), P. 121.
} 
Kenyatta was freed the same month..$^{92}$ They further requested the governor of Kenya Colony to construct a house for Kenyatta after a long period of his detention. The governor agreed to build a house for Kenyatta and KADU members supervised the construction until its completion. ${ }^{93}$ This showed that until the release of Kenyatta, it was the hard work of Toweett and KADU members who knew the strength of Kenyatta in uniting the country.

\section{Second Lancaster House in 1962}

In 1960 KANU and KADU had good number of representatives in Legco; all these parties produced delegates to Second Lancaster House. ${ }^{94}$ Despite two parties were going for the same conference, they had different grievances to table to the colonialist. KADU was advocating for devolved system of government while KANU wanted centralized form of government. ${ }^{95}$ In the opening speech, Toweett elaborated the importance of devolved government. He said that power will be shared and felt by everyone, corruption will be dealt with effectively and political dominance will be controlled hence people especially leaders will not become tribal. The idea of Toweett was accepted and adopted by African leaders and they all supported the regionalism system of governance. Another proposal of KADU through Toweett was bilateral form of parliament which was unanimously accepted by the African leaders. ${ }^{96}$

In 1963 when KANU took leadership of the country, they went against the Second Lancaster Talk and they got rid of the bicameral parliament and devolved government. ${ }^{97}$ KANU and KADU agreed to form a coalition government and they pushed African demands in the talks. After the talks Toweett, Ronald Ngala and Kenyatta were appointed Ministers. ${ }^{98}$ Kenyatta was Minister for

\footnotetext{
92 Raphael Kitur, OI, $21^{\text {st }}$ July 2021.

${ }^{93} \mathrm{KNA} / \mathrm{PC} /$ /KC, Weekly Review, Release of Kenyatta, 1961, Section (ii).

94 T. Toweett, Unsung Heroes of Lancaster: Call a Spade a Spade Historical Memoir, (longhorn publishers), p. 54.

${ }^{95} \mathrm{KNA} / \mathrm{DC} / \mathrm{AN} / \mathrm{KC} / 7 / 10 / 12$, East Africa Standard, KANU and KADU demands, 1962, p.5.

${ }^{96}$ Frankline Chepkoit, OI, $21^{\text {st }}$ July 2021.

${ }^{97} \mathrm{KNA} / \mathrm{KC} / \mathrm{DC} / \mathrm{PS} / 1 / 6 / 7$, Weekly Review, KANU takeover, 1962, p.3
}

economics and rural development, Toweett retained Minister for Local Governments. ${ }^{99}$ Differences among the African leaders remerged again as KADU blamed KANU for killing the devolved government while KANU accused KADU to be full of traitors who related with the Europeans in the government. ${ }^{100}$ In 1963 general elections, KADU and KANU were the main parties competing for the seats among Africans. Toweett was campaigning for KADU and he contested for Bureti parliamentary seat with the KADU ticket. ${ }^{101}$ KANU was losing after KADU formed a strong coalition with APPA. Due to differences between the two parties, the coalition did not last long thus gave a chance for KANU to win majority of the parliamentary seats both in lower and Upper Houses. ${ }^{102} \mathrm{KADU}$ won in all the constituencies in Rift valley as it was the dominant party in the region.

In 1963 March, Kenyatta was sworn in as the first Prime Minister of the republic of Kenya. Toweett demanded for the rule of law to be applied, Toweett party KADU had the minority members in both houses, and it acted as the opposition party. ${ }^{103}$ KADU wanted regional government while KANU voted for centralized government which was later the one imposed. In the same year, Dancan Sondly conveyed a meeting with African leaders in London; he fixed the constitution and made it tedious for the African leaders to alter. He adjusted the qualifications for the political parties to amend the constitution thus making it difficult for Africans to change the constitution. ${ }^{104}$ The proposal of Sondly forced African leaders to come together and put aside their differences so that they work towards attainment of independence. The unity of Africans against the recommendation of the Secretary of the

\footnotetext{
${ }^{98}$ Ibid, p. 4.

${ }^{99}$ G. W. Gona, A political biography of Gideon Ngala; (MA Thesis University of Nairobi; 1991), P. 130

${ }^{100}$ Raphael Kitur, OI, $21^{\text {st }}$ July 2021.

101 T. Toweett, Unsung Heroes of Lancaster: Call a Spade a Spade Historical Memoir, (longhorn publishers), p. 54.

102 Ibid, p. 55.

103 Ibid, p. 57.

104 T. Toweett, 'Epitaph on Colonialism and Shorter Poems, (Longhorn Publishers; 1989), p. 40.
} 
Colony Dancan Sondly earned the country independence in $196312^{\text {th }}$ December. ${ }^{105}$

\section{CONCLUSION}

This paper has demonstrated the undertakings of Toweett in the struggle for independence. He played a crucial role from the time he was appointed to the Legco in 1958. Toweett was the first LegCo member representing Southern Electorate Area. He also became the first Member of Parliament representing Bureti Constituency after the demarcation of boundaries which created more constituencies in 1961. Toweett is portrayed as one of the prominent leaders whose political impacts were felt in the fight for achievement of independence of Kenya. When he was elected in the LegCo in 1958, he was one of the members of the AEMO who aimed to unite the African leaders to fight for a common objective. He was one of the pioneering leaders of the AEMO and CEMO. The two organizations comprised of all African leaders elected to the LegCo and the aim was to bring unity and togetherness among the elected leaders.

Toweett was eloquent and fearless leader in the LegCo debates. He tabled the demands of the Africans without fearing the intimidations from the Europeans administrators. When he was appointed the Assistant Minister for Agriculture and co-opted member of Cabinet, Toweett continued to agitate for the grievances of Africans directly to the Governor of the Kenya Colony. He was one of the members who were punished for holding a press conference and mobilizing the Africans to continue protesting for their rights to be heard by the colonialist.

Toweett was one of the leaders who challenged the Lennox Boyd and the Littleton constitutions which were brought by the Europeans to marginalize the Africans in their own original homeland. He preferred peaceful negotiation means to be applied in the gaining for independence. Toweett was one of the resourceful leader and wise thinkers who was consulted always by other African leaders. He was appointed in both the first and second Lancaster House Conferences which aimed at coming up with a constitution that would govern the African countries and give them independence. The Second Lancaster Conference gave Kenya independence in 1963. Toweett's contributions in both conferences was of great impact to the achievement of independence. Indeed, Toweett emerged as one of the unsung Hero of the Lancaster house.

Additionally, Toweett participated in formation of national political parties which helped African leaders to unite and fight for a common interest. They used these parties to channel their grievances and demands of Africans. He participated in the establishment of the constitution which guided the country after it gained independence in 1963. He is one of the pillars and supporters of KANU, a political party which exists up to now and was used by Kenyatta the first president to gain independence.

The historiography of Dr Taaita Toweett has remained unearthed in the history of colonial heritage. His political journey sums up the current and contemporary leaders in our country and Africa at large. The recommendation of this study suggests further analysis on the writings of Toweett about the struggle for independence in his six books, the political journey of Toweett after independence and the track record on development of Bureti and Legacies he left in various ministries he served after independence.

105 T. Toweett, Unsung Heroes of Lancaster: Call a Spade a Spade Historical Memoir, (longhorn publishers), p. 61.

14 | This work is licensed under a Creative Commons Attribution 4.0 International License. 